\title{
The discourse of health managers on aspects related to the delay in tuberculosis diagnosis*
}

\author{
A DISCURSIVIDADE DE GESTORES SOBRE ASPECTOS RELACIONADOS AO \\ RETARDO DO DIAGNÓSTICO DE TUBERCULOSE
}

\section{LA DISCURSIVIDAD DE GESTORES SOBRE ASPECTOS RELACIONADOS AL RETARDO DEL DIAGNÓSTICO DE LA TUBERCULOSIS

\begin{abstract}
Lenilde Duarte de Sá ${ }^{1}$, Anne Jaquelyne Roque Barrêto², Jordana de Almeida Nogueira3, Fátima Teresinha Scarparo Cunha ${ }^{4}$, Pedro Fredemir Palha ${ }^{5}$, Tereza Cristina Scatena Villa ${ }^{6}$
\end{abstract}

\begin{abstract}
The aim of this study was to analyze the discourse of health managers on aspects related to delay in tuberculosis diagnosis. This was a qualitative research study, conducted with 16 Family Health Unit managers. The empirical data were obtained through semi-structured interviews. The analysis was based on the theoretical framework of the French school of discourse analysis. According to the managers' statements, the delay in tuberculosis diagnosis is related to patient and health service aspects. As for patient aspects, managers report fear, prejudice and lack of information as factors that may promote a delayed diagnosis. Regarding health service aspects, structural problems and lack of professional skills were reported. The discourse of managers should be considered to qualify tuberculosis control actions and to prevent delays in diagnosis.
\end{abstract}

\section{DESCRIPTORS}

Tuberculosis

Delayed diagnosis

Health management

Health Services

Publichealthnursing

\section{RESUMO}

O objetivo deste estudo foi analisar a discursividade de gestores sobre aspectos relacionados ao retardo do diagnóstico da tuberculose. Pesquisa de natureza qualitativa, que envolveu 16 gestores de Unidades de Saúde da Família. O material empírico foi produzido por meio de entrevistas semiestruturadas. $\mathrm{Na}$ análise foi utilizado como dispositivo teórico-analítico a análise de discurso de linha francesa. Segundo os discursos dos gestores, o retardo no diagnóstico de tuberculose relaciona-se ao usuário e aos serviços de saúde. Com relação aos usuários, o discurso dos gestores evidencia o medo, o preconceito e a falta de informação como fatores que promovem o retardo do diagnóstico. A respeito dos serviços de saúde, fazem referência a dificuldades estruturais e falta de qualificação profissional. Convém observar as interpretações dos gestores para qualificar as ações de controle da tuberculose visando prevenir o atraso do diagnóstico da doença.

\author{
DESCRITORES \\ Tuberculose \\ Diagnóstico tardio \\ Gestão em saúde \\ Serviços de Saúde \\ Enfermagememsaúdepública
}

\section{RESUMEN}

El objetivo de este estudio fue analizar el discurso de gestores sobre aspectos relacionados al retardo del diagnóstico de la tuberculosis. Investigación de naturaleza cualitativa, que involucró a 16 gestores de Unidades de Salud de la Familia. El material empírico fue producido por medio de entrevistas semi-estructuradas. En el análisis fue utilizado como dispositivo teórico-analítico, el análisis del discurso, de línea francesa. Según los discursos de los gestores, el retardo en el diagnóstico de la tuberculosis se relaciona con el usuario y los servicios de salud. Con relación a los usuarios, el discurso de los gestores evidencia el miedo, el prejuicio y la falta de información como factores que promueven el retardo del diagnóstico. Al respecto de los servicios de salud, los sujetos mencionan dificultades estructurales y falta de calificación profesional. Conviene observar las interpretaciones de los gestores para calificar las acciones de control de la tuberculosis, con miras a prevenir el retraso del diagnóstico de la enfermedad.

\author{
DESCRIPTORES \\ Tuberculosis \\ Diagnóstico tardío \\ Gestión en salud \\ Servicios de Salud \\ Enfermería en salud pública
}

\footnotetext{
${ }^{1}$ Part of the master's thesis "Retardo no diagnóstico da tuberculose e a influência dos aspectos relacionados à gestão" Federal University of Paraíba Graduate Program in Nursing, $2010{ }^{1}$ Nurse. Doctorate in nursing, Ribeirão Preto School of Nursing, University of São Paulo. Professor at the Public Health Nursing and Mental Health Department, Health Sciences Center, Federal University of Paraíba. João Pessoa, PB, Brazil. lenilde_sa@yahoo.com.br ${ }^{2}$ Nurse.

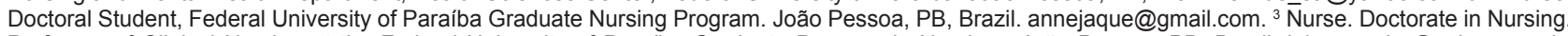
Professor of Clinical Nursing at the Federal University of Paraíba Graduate Program in Nursing.. João Pessoa, PB, Brazil. jal_nogueira@yahoo.com.br ${ }^{4}$ Nurse. Doctorate in Public Health by the State University of Rio de Janeiro Institute of Social Medicine. Professor at the Federal University of the State of Rio de Janeiro. Rio de Janeiro, RJ, Brazil. fatima.scarparo @ gmail.com ${ }^{5}$ Nurse. Associate Professor, Public Health Department, Ribeirão Preto School of Nursing, University of São Paulo. Ribeirão Preto, SP, Brazil. palha@eerp.usp.br ${ }^{6}$ Nurse. Full Professor, Public Health Department, Ribeirão Preto School of Nursing, University of São Paulo. Ribeirão Preto, SP, Brazil. tite@eerp.usp.br
} 


\section{INTRODUÇÃO}

Diagnosis delay is one of the major challenges for health managers and healthcare workers in the current scenario of the Brazilian fight against tuberculosis (TB $)^{(1-4)}$.

The problem is associated with both patient and health system aspects ${ }^{(5-6)}$. Patient delay is defined as the period between the onset of TB symptoms until the first presentation to any healthcare facility. Health system delay is defined as the time interval between the first medical appointment in any healthcare facility and the date of diagnosis confirmation. Total delay is the sum of patient delay and health system delay ${ }^{(5)}$.

The aim of this study was to interpret health managers' discourses on aspects associated to delayed TB diagnosis, focusing both on patient and health system delay. The opinion of managers can indicate ways to increase agility in diagnostic confirmation by identifying barriers related to health services and patients. An early diagnosis allows the start of TB treatment as soon as possible, the safeguard of case contacts, and the minimization of patient suffering.

We emphasize that there is no consensus about the criteria to define the length of a delayed TB diagnosis, being that other studies indicate that patient delay can range from 30 to 162 days, and health system delay, from two to 18 days $^{(5-6)}$.

National and international literature is sparse regarding an acceptable time frame for TB diagnosis. However, to achieve effective control of the disease, the patient delay should not be longer than two or three weeks. The health system delay should only last a few days, since the sputum test can be requested and performed immediately and onsite $^{(6)}$. Therefore, the ideal total time for diagnosis should not exceed 3-4 weeks for most smear-positive TB cases $^{(6)}$.

In northern and southeastern Brazil, studies showed some of the factors associated with patient and health system delay ${ }^{(1-3)}$, confirming the results observed in international literature. Regarding patient delay, poor living conditions, unemployment, low education, low wages, and being a female aged over 60 years are indicated as important factors. Studies identify the lack of professional skills, health service bureaucratization to perform TB detection and diagnosis, low TB suspicion, delay in test results delivery, shortage of health professionals, and lack of continuity in care as associated with health system delay ${ }^{(1-3)}$.

The health services organization directly affects the access of patients to health care ${ }^{(7)}$. In turn, patients' care- seeking behavior before the disease, as well as economic and cultural aspects, can interfere with early confirmation of the diagnosis.

Considering health management as a field of political action, it is up to the health manager to decide where he/she desires to go, what he/she wants to achieve and the ways to do it, including how to remove obstacles for patients to access health services, then accomplishing the desired targets ${ }^{(8)}$. As the person responsible for the health of people in a delimited area in the city, and based on the right to health, the manager needs to have specific knowledge and skills of coordination, and above all, ideological affiliation with paradigms that promote changes in the hegemonic model of health services organization. Otherwise, his/her position will strengthen a health model rooted in the biomedical concept, slowing progress of universal health models based on comprehensiveness and equity.

In Brazil, few studies have investigated delay in TB diagnosis, especially with a focus on the managers' perspective, the one responsible for the health services organization. No studies were found related to the managers' discourse and their opinion about the causes of this problem.

Considering discourse as a scattering of texts, and text as a dispersion of the subject ${ }^{(9)}$, we intended to understand the meanings of language, as a symbolic work, part of the collective social activity, constitutive of man and his history ${ }^{(9)}$. The comprehension of such an event is essential, once the delay in diagnosis compromises the healing process and increases the spread of the bacillus, the severity of the disease and the occurrence of TB-related deaths ${ }^{(2)}$.

Interpreting the discourse of managers on issues related to delayed diagnosis of TB, considering health service organization and the associated patient factors, may contribute to the early detection of cases, to the decrease of TB incidence and especially to the promotion of the effectiveness of TB control in Primary Health Care (PHC) settings.

Thus, this research aimed to analyze managers' discourse on aspects related to delayed diagnosis of tuberculosis in one city of João Pessoa, in the metropolitan area.

\section{METHOD}

Qualitative research conducted through semi-structured interviews with managers of Family Health Units (FHU). The study setting was a city in the metropolitan area of João Pessoa, PB, considered by the Brazilian Ministry of Health as a priority county for TB control.
The discourse of health managers on aspects related to the delay in tuberculosis diagnosis Sá LD, Barrêto AJR, Nogueira JA, Cunha FTS, Palha PF, Villa PCS 
The health services selected for the study were chosen from Primary Health Care (PHC), represented by units of the Family Health Strategy (FHS). Among a total of 180 health teams, 21 were considered as integrated, i.e., three to four teams share the same physical space inside the unit. Besides the basic healthcare staff, each integrated health unit has one to two management supporters (MS). The 16 subjects who participated in this study were MS of these units.

The MS were members of the FHU staff since 2007 and were chosen for this study due to their role as facilitators in the redesign of health practices, aiming to establish the bond and accountability of health teams towards a comprehensive care in the local area. They were health workers who assumed management functions and the linkage of the health unit to their sanitary districts. The discourse of these professionals was essential to understand factors associated with delayed diagnosis of TB, a priority disease for PHC policy in Brazil.

The following inclusion criteria were considered: to be a MS in an integrated FHU, be a resident of the study setting, to accept participation in the study, to answer the study instrument and to sign the Consent Form. To ensure anonymity, the participants were identified by the letter $M$ ( $M$ stood for manager) and arranged in a sequence of 1 to 16 .

Data collection was conducted through interviews with 16 MS between August and September of 2009. The interviews were recorded and transcribed. We used the theorical framework of the French school of discourse analysis $^{(9)}$. The elaboration of the empirical material was conducted based on the following question: What does the discourse of managers reveal about the delayed diagnosis of TB?

The Atlas.ti version 6.0 was used to systematize data. This process favored the identification of tracks that allowed the understanding of how speech acts produce me- aning $^{(9)}$ about the factors related to delayed TB diagnosis, considering both patient and health system delays.

In the second stage of the analysis the paraphrasic, polysemic and metaphorical processes of the statements were observed, enabling the identification and selection of discursive sequences. Those discursive sequences were grouped into two Discursive Formations (DF): patient aspects influencing diagnosis delay and health service aspects influencing diagnosis delay.

The DF allowed the comprehension of the different meanings in managers' discourses regarding delayed TB diagnosis aspects. These different meanings in MS statements were organized into discursive sequences and discursive fragments (chart 1 and chart 2). The discursive fragments that characterized the statements were analyzed considering the interviewee's ideological position, his relationship with other statements, historical interdiscursive affiliations and discursive memory.

To understand the relationship of health services with the delayed TB diagnosis we also analyzed the local health plan, which was a guideline for health policy and practice that permeated local health management. Between managers' discourse and the local health plan ${ }^{(10)}$, we aspired to identify contradictions of what was set by the document and the interviewees' opinions revealed in their statements.

The study was part of a project approved by the Board of Ethics from the Health Sciences Center of the Federal University of Paraíba (CCS/UFPB) on December 17, 2008 (process number 0589), following the ethical and legal guidelines for studies involving human subjects (Resolution CNS/MS 196/96).

\section{RESULTS}

The description of DF 1 - entitled as patient aspects influencing delay in TB diagnosis is found in chart 1, with the following sequences and discursive fragments.

Chart 1 - Patient aspects influencing delay in TB diagnosis - João Pessoa, PB, Brazil, 2009

Discursive sequences

...the patient is afraid;...there is still a prejudice; there is shame to say he/she has TB...

Discursive fragments

And also due to the barrier of fear from patients that the community will know [about the disease] ... that there is still stigma, especially from those poorest communities. (...) And they [users] say it is because they were ashamed (G3)

And with feelings of shame or prejudice, patient distrusts and then goes straight to the reference hospital. [In the reference hospital when] positive diagnoses come back to the team, and often [patients] do not want to return to the team, by the shame that is to say one has TB (G7).

reluctance comes from the patient himself...;

...the patient is so reluctant to go to the medical appointment... ...which makes it difficult ... (...) is the user's own resistance to discover whether or not he/she has tuberculosis. Sometimes he resists going to the health unit "(G1).

This user is so resistant to the medical appointments, not wanting to go to the health unit because he/she already thinking $T B(G 11)$.
...TB remains unknown...; ..they relate (the symptoms) to everything but TB...
.. by being so old, it [tuberculosis] is not yet a disease that people recognize, then any respiratory problem is associated with virus diseases, flu, smoke, dust of the street, all but a disease like tuberculosis. (...) (G10).
The discourse of health managers on aspects related to

the delay in tuberculosis diagnosis

Sá LD, Barrêto AJR, Nogueira JA, Cunha FTS, Palha PF, Villa PCS
Rev Esc Enferm USP

2013; 47(5):1165-71

www.ee.usp.br/reeusp 
The description of DF 2 - entitled as health service asThe following sequences and discursive fragments compopects influencing delay in TB diagnosis is found in chart 2.

sed the discursive materiality.

Chart 2 - Health service aspects influencing the delay in TB diagnosis - João Pessoa, PB, Brazil, 2009

\begin{tabular}{|c|c|}
\hline Discursive sequences & Discursive fragments \\
\hline $\begin{array}{l}\text { In regard of the city... I do not } \\
\text { see much barriers to diagnosis...; } \\
\text { As a manager, I see no trouble }\end{array}$ & $\begin{array}{r}\text { The diagnosis is fast; the flow is very organized now. And so, in regard to the city, I do not see (...) much } \\
\text { hindering diagnosis }(G 1) \text {. } \\
\text { Today I do not see, as a manager, any difficulty, (...), for example, the sputum test, we do collect the sputum } \\
\text { directly in the user's home (...). So the user has no difficulty to perform it, if there is any doubt, he/she comes } \\
\text { and does the exam, patients come here already with the result }(G 9) .\end{array}$ \\
\hline $\begin{array}{c}\text { Issue of transport...; } \\
\text {... Issued of structural capacity; } \\
\text { it seems there is only one } \\
\text { biochemist; ... a laboratory is } \\
\text { doing the analysis; ... they spent } \\
\text { a lot of time without someone } \\
\text { to take the exams... we are } \\
\text { organizing it more and more... } \\
\text { the network is very big. }\end{array}$ & $\begin{array}{l}\text { The delay has several causes. You have the issues of transport, the question of an insufficient laboratory. It's a } \\
\text { laboratory that does not only perform clinical analysis for tuberculosis, but for many other things (...) then we } \\
\text { also realize that there is a difficulty with the availability of biochemist there. It seems that they only have one } \\
\text { biochemist. Then all exams take more time. These are the difficulties; they are structural (G2). } \\
\text { We spent a lot of time without the guy who used to deliver the tests [material collected]. (...) As for the test } \\
\text { result, they don't call back. (...)... I think that we are organizing this more and more; ... the network is very } \\
\text { large (...) (G5). }\end{array}$ \\
\hline $\begin{array}{l}\ldots \text { Not everyone understands } \\
\text { how the treatment works; } \\
\text { Weaker professionals; ... the } \\
\text { professionals are not qualified }\end{array}$ & $\begin{array}{c}\text { Not everyone understands what is the process and how it is going to happen, how the treatment works. As for } \\
\text { us, the supporters, we have always tried to support trainings on it and then we have seen deficiencies in the } \\
\text { professionals at the health units (...) (G4). } \\
\text { The question comes out from the professionals themselves, who are not qualified to perform the diagnosis (G5). }\end{array}$ \\
\hline $\begin{array}{l}\text {... We have not been acting } \\
\text { enough... No work has been } \\
\text { done... community participates } \\
\quad \text { in lectures ... }\end{array}$ & $\begin{array}{c}\text { As we still have not done any macro action [to TB], as they say, involving everyone, what we have done is } \\
\text { more a conversation in the waiting room and I have not seen much resistance to it (G3). } \\
\text { So, if any work [educational activity for TB] has been done until now, I cannot answer you. But I did it } \\
\text { that day, it was the International Day Against Tuberculosis, there in the Bishop's Island, the population has } \\
\text { attended lectures, they asked questions (G15). }\end{array}$ \\
\hline
\end{tabular}

\section{DISCUSSION}

In their statements, managers related patient delays to feelings such as fear and shame, this last linked to a prejudice that has been following the disease for millennia, and also to the possibility of perceiving him/herself sick in front of the family and the community ${ }^{(11)}$.

During the TB diagnosis process, the fear and the shame of being sick are associated mainly with family and society rejection ${ }^{(12)}$, as the patient is considered a potential harm by infecting healthy people. For that, people with TB have been excluded, almost compulsorily, of the familiar and of society conviviality. Authors named the experience of exclusion the social death - the first death of those infected ${ }^{(12)}$.

In the relationship between discursive fragments and the cultural-anthropological field, despite the availability of treatment and cure, a discursive memory updates the TB stigma for the present time in terms of both intra- and inter-discourse. So, from the symbolic perspective, stigma continues to be associated with TB.

We observed that patient resistance in seeking health services existed due to the impossibility of changing his/ her own health identity status. The diagnosis confirmation implied an alteration in identity due to the function of a disease based on stigma and incapacities. In some cases, in addition to the fear of discovering the TB disease, there was also a fear of the loss of a job due to the disease, causing a reduced income ${ }^{(13-14)}$ for patients and/ or the lost of the family sustenance.
While acknowledging the influence of stigma and other cultural factors ${ }^{(15)}$ in the diagnosis and treatment pathway, we did not identify actions to transform embedded behaviors linked to stigma among the manager statements. Managers remained silent regarding behavior change practices and did not support patients' attitudes that might shorten the diagnostic process.

The recognition that stigma is a barrier to early diagnosis should be considered by health professionals and managers as an indication to plan and implement TB control activities, so that an advised patient, when he felt sick or identified some classic TB symptom, worried about seeking diagnosis in health services without fearing the negative publicity of a status that would disqualify him/her in front of the family and the community.

The patients' delay in seeking care can contribute to aggravating the situation by making treatment more difficult. And, while the infectious process continues, this increases the chance of transmitting the disease to others ${ }^{(16)}$. Health education activities based on solid transformative concepts can help in coping with prejudice against TB.

Managers considered the lack of information about TB, both from the patient and from the population, as one of the barriers to an early diagnosis. Symptoms were interpreted as being related to respiratory diseases other than TB, which contributed to a delay in seeking care and diagnosis.

According to the Guidelines for Tuberculosis Control, FHS staff are responsible for the development of 
educational activities with service users and the community ${ }^{(17)}$. Among priority actions for TB control, health education activities should be conducted with the population of the delimited areas of the $\mathrm{FHU}^{(10)}$. Such activities should be oriented by relevant themes to patients, families and community.

In their statements, managers mentioned that specific health education activities covering information on TB were developed with the population, but were centered around the traditional framework of health education. Activities in this field have not been based on the PHC perspective, and were reduced to lectures and individual guidance in the unit waiting room. In this form of educational activities, we recognized ideological affiliations contrary to those aimed toward the transformation of reality, such as those theoretically aligned to the liberating framework of Paulo Freire, designed toward popular health education and based on the permanent health education (PHE) paradigm. As for the investment in perspective transformations, the process of health education should combine acquisition of information and basic skills with a sense of identity, autonomy, solidarity and responsibility of individuals and communities for their own health ${ }^{(18)}$.

Considering the severity of TB disease and the extent of its social problems, especially in large urban centers as is the case of this study setting, the actions of health education should consider the disease process, especially to inform the importance of early diagnosis, both for the individual, the family and community.

There is an obvious contradiction in the statements of managers about the health service organization and its relationship with delayed diagnosis of TB. Initially, as defenders of the local health system, they affirmed that there was no difficulty in obtaining TB diagnosis in the city. However, when asked directly about factors that contributed to delayed diagnosis, in the thread of the discourse that permeated the fragments, they denounced structural deficiencies, lack of professional qualification, shortage of professionals, among others. The managers themselves did not have certainty about the amount of professionals engaged in an important role of diagnostic confirmation, as stated: then we also learned about the lack of biochemists there. It seems that they only have one biochemist.

Justifications for the delayed diagnosis were also found among the statements, when one of the subjects attributed it to the extension of the health services network. In contrast to the extent of the network, the importance of planning TB control was emphasized, not only within the $\mathrm{PHC}$, but also in all points that comprised the local health care network. Managers and health workers must recognize that the health services organization contributed to the delay of diagnosis when there was a lack of devices for early case detection, absence of reflection on the work process, deficiencies in priority setting and service evalua- tion. The insertion of strategic planning and health service evaluation tools contribute to effective TB control.

According to the local health plan, which provides the principles on organization of health services in the study setting, health services should be oriented about guidelines for effective comprehensive care. The dissonant statements of some managers revealed another ideological alignment to what was set in the document. It is relevant to highlight that managers, through their actions, reaffirmed the commitment of a local health system where care and respect for people should permeate all services ${ }^{(10)}$.

Regarding access to diagnostic confirmation, it is important to note that managers seemed to be absent in terms of measures that promoted early case detection, as well as strategies that streamlined access to diagnosis and treatment. Access was defined as an attribute that mediated the relationship between demand and entry into the health service. It included a utilization of health services that was adequate to the person's needs, geographically satisfactory, and that occurred in a timely and resolute manner ${ }^{(19)}$. Access was a multidimensional concept that expressed a set of supply characteristics. As access could block or enhance peoples' ability to use health services, it is essential for managers to recognize the barriers associated with this attribute.

Managers should consider that the mere availability of resources does not guarantee access ${ }^{(19)}$ and that articulation is an essential dimension in this process. In some MS statements, the recognition of difficulties related to achieve TB diagnosis denoted sensitivity to the need for adjustment. The current government triggered this change, aiming, minimally, for the reorganization of health services for early detection, diagnosis, treatment and adequate follow-up of people with the disease.

However, in any change process, tensions arise from the correlation of forces from hegemony and counter-hegemony sides. Institutional interventions for this rupture with the crystallized and established movements demand the comprehension that every change is punctuated by crises, conflicts, consensus and disagreement. Dialectically, in this struggle of opposites, new shapes and alternative designs to what is seen can be constructed and deconstructed and, possibly, a new way of working may arise, more fraternal and united, more respectful to differences and to diversity ${ }^{(20)}$.

By recognizing the structural difficulties faced in health work and management dynamics, some managers favored actions for the redesign of services in order to reduce delay in diagnosis and reach effective TB control. In this sense, the sentence more and more we are organizing reports that changes are being made during this process.

We identified among some managers' statements (G4, $\mathrm{G5}$ ) the lack of knowledge of some professionals regar- 
ding the disease, mainly related to the definition of the diagnosis and its treatment. Other studies discussed the low level of TB suspicion by health professionals and inadequate control of the disease as determinants for a delayed diagnosis ${ }^{(14,21)}$. To address problems with TB knowledge and expand case detection, it is necessary to qualify not only health professionals, but also all workers in the health service.

The PHE was a tool adopted by the city administration, as informed by the local health plan, to stimulate critical reflection on problems related to actions and behavior of subjects through the strategy of learning ${ }^{(10)}$. The PHE presumes learning by doing and that the learning and teaching process is incorporated into the daily life of organizations. It is based on meaningful learning and the possibility of translating knowledge into professional practices. Problems identified in reality should be addressed using knowledge and experiences that people already have ${ }^{(22)}$.

Based on these, it is essential for MS to incorporate this type of knowledge into their actions, so that they can act as historical subjects of transformation in management and for the improvement of practices developed in the health services. In regard to the aim of this study, managers may act by identifying and removing barriers that hindered access to early diagnosis and TB control, considering this activity as strategic for PHC.

Managers should recognize the magnitude of the changes, shaking the symbolism built and established throughout history. Likewise, it is important that central management promotes the qualification of these supporters with emphasis on priority areas for PHC in Brazil, in order to align their statements and promote effective actions and creative strategies. When the speech is opaque with respect to what is done, we can suggest that alienation is occurring. The working class alienation, in this case among healthcare workers, contributes to the resistance to change. The alienation weakens healthcare practice and slows change.

\section{REFERENCES}

1. Maciel EL, Golub JE, Peres RL, Hadad DJ, Fávero JL, Molino $\mathrm{LP}$, et al. Delay in diagnosis of pulmonar tuberculosis at a primary health clinic in Vitoria, Brazil. Int J Tuberc Lung Dis. 2010;14(11):1403-10.

2. Silva-Sobrinho RA, Andrade RLP, Ponce MAS, Wysocki AD, Brunello $M E$, Scatena LM, et al. Retardo no diagnóstico da tuberculose em municípios da tríplice fronteira Brasil, Paraguai e Argentina. Rev Panam Salud Publica. 2012;31(6):461-8.

3. Machado ACFT, Steffen RE, Oxlade O, Menzies D, Kritski A, Trajman. Fatores associados ao atraso no diagnóstico da tuberculose pulmonar no estado do Rio de Janeiro. J Bras Pneumol. 2011;37(4):512-20.
The manager should consider that his role is to produce a process of institutionalization, working always across the tension of what is established and what establishes, between the order that sustains the productive processes and the disorder of creative and change processes. It takes courage and determination to break with this process ${ }^{(20)}$ and to be able to practice differently, it is imperative to confront and add to it knowledge and reflection.

\section{CONCLUSIONS}

By analyzing managers' discourse on aspects associated with delay in TB diagnosis, this study revealed information that added knowledge to the scientific debate on factors related to this event, linked to patients and health service characteristics.

The managers emphasized the cultural conditions in which stigma acted as one of the main barriers to accessing health services, therefore associated with a delayed diagnosis. Historical conditions cross the participant statements when attributing the phenomenon of delayed diagnosis to the behavior of patients.

Regarding health services, managers reported structural problems, lack of knowledge on TB among health professionals, and lack of skills for TB clinical management. The speech is vague when it comes to innovative actions to fight the disease, especially to promote timely diagnostic confirmation.

In order to minimize cases of alienation, the municipal administration should develop the qualification of MS, so that they could incorporate care management concepts and methodologies against the historically hegemonic practices that prevent knowledge on comprehensive care.

The lack of Brazilian studies focusing on managers' statements about delayed TB diagnosis justifies the limitations of the discursive formation discussion. We suggest that further studies are necessary, contemplating the discourse of patients and healthcare workers.
4. Albuquerque MFPM, Ximenes RAA, Lucena-Silva N, Souza WV, Dantas AT, Datas OMS, et al. Fatores associados com falência terapêutica, abandono e óbito em uma coorte de pacientes com tuberculose acompanhados no Recife, Pernambuco, Brasil. Cad Saúde Pública. 2007;23(7):1573-82.

5. Basnet R, Hinderaker SG, Enarson D, Malla P, Morkve O. Delay in the diagnosis of tuberculosis in Nepal. BMC Public Health. 2009;9:236.

6. Lambert ML, Van Der Stuyft P. Delays to tuberculosis treatment: shall we continue to blame the victim? Trop Med Int Health. 2005;10(10):945-6.
The discourse of health managers on aspects related to the delay in tuberculosis diagnosis Sá LD, Barrêto AJR, Nogueira JA, Cunha FTS, Palha PF, Villa PCS 
7. Jamal LF, Moherdaui F. Tuberculose e infecção pelo HIV no Brasil: magnitude do problema e estratégias para o controle. Rev Saúde Pública. 2007;41Supl.1:104-10.

8. Grabois V, Ferreira SCC. Gestão em Saúde: perspectivas e desafios para a construção da integralidade. In: Ferreira SCC, Monken M, organizadores. Gestão em saúde: contribuições para análise da integralidade. Rio de Janeiro: EPSJV; 2009. p.157-71.

9. Orlandi EP. Análise de discurso: princípios \& procedimentos. São Paulo: Pontes; 2009.

10. João Pessoa. Secretaria Municipal de Saúde. Plano Municipal de Saúde: 2006-2009. João Pessoa: SMS; 2006.

11. Pôrto A. Representações sociais da tuberculose: estigma e preconceito. Rev Saúde Pública. 2007;41Supl.1:43-9.

12. Bertolli Filho C. História social da tuberculose e do tuberculoso: 1900-1950 [Internet]. Rio de Janeiro: FIOCRUZ; 2001 [citado 2011 out. 25]. Disponível em: http://static.scielo. org/scielobooks/4/pdf/bertolli-9788575412886.pdf

13. Courtwright A, Turner AN. Tuberculosis and stigmatization: pathways and interventios. Public Health Rep [Internet] 2010 [cited 2011 Oct 02];125 Suppl 4:34-42. Available from: em: http://www.publichealthreports.org/archives/issueopen.cfm?articleID $=2481$

14. Dag SG, Yimer S, Bjune AG. A systematic review of delay in the diagnosis and treatment of tuberculosis. BMC Public Health. 2008;8:15.

15. Clementino FS, Martiniano MS, Clementino MJSM, Sousa JC, Marcolino EC, Miranda FAN. Tuberculose: desvendando conflitos pessoais e sociais. Rev enferm UERJ. 2011;19(4):638-43.
16. Baral SC, Karki DK, Newell JN. Causes of stigma and discrimination associated with tuberculosis in Nepal: a qualitative study. BMC Public Health. 2007;7:211.

17. Brasil. Ministério da Saúde; Secretaria de Vigilância em Saúde, Departamento de Vigilância Epidemiológica. Manual de recomendações para o controle da tuberculose no Brasil [Internet]. Brasília; 2011 [citado 2012 mar. 13]. Disponível em: http://portal.saude.gov.br/portal/arquivos/pdf/manual_de_recomendacoes_tb.pdf

18. Brasil. Ministério da Saúde; Fundação Nacional de Saúde. Controle da tuberculose: uma proposta de integração ensino-serviço. Brasília: Ministério da Saúde; 2002.

19. Travassos C, Castro MSM. Determinantes e desigualdades sociais no acesso e na utilização de serviços de saúde. In: Giovanella L, Escorel S, Lobato LVC, Noronha JC, Carvalho Al, organizadores. Políticas de Sistema de Saúde no Brasil. Rio de Janeiro: FIOCRUZ, 2008. p. 215-43.

20. Campos GWS. Saúde paidéia. 3a ed. São Paulo: Hucitec; 2007.

21. Kiwuwa MS, Charles K, Harriet KM. Patient and health service delay in pulmonary tuberculosis patients attending a referral hospital: a cross-sectional study. BMC Public Health. 2005;5:122.

22. Ceccim RB. Educação permanente em saúde: desafio ambicioso e necessário. Interface Comun Saúde Educ. 2005;9(16):161-77.

\section{Acknowledgements}

To the multicenter project "Delay in the diagnosis of tuberculosis: causal analysis in different regions of Brazil", approved and sponsored by the National Council of Technological and Scientific Development (MCT/ CNPq/CT-Saúde/MS/SCTIE/DECIT 034/2008). 